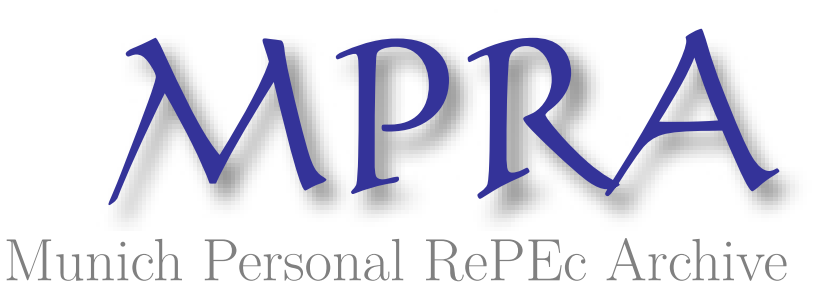

\title{
Water transfers in El Paso County, Texas
}

Fullerton, Thomas

2006

Online at https://mpra.ub.uni-muenchen.de/432/

MPRA Paper No. 432, posted 13 Oct 2006 UTC 
Water Policy 8 (2006) 255-268

\title{
Water transfers in El Paso County, Texas
}

\author{
Thomas M. Fullerton Jr. \\ Department of Economics and Finance,University of Texas at El Paso, El Paso, TX 79968-0543, USA. Tel: +1-915-747-7747. \\ Fax:+1-915-747-6282.E-mail:tomf@utep.edu
}

Received 11 November 2004; accepted in revised form 18 February 2005

\begin{abstract}
Water rights transfers for surface water have taken place in El Paso County in far west Texas for many decades. Historically, these exchanges have primarily occurred between agricultural water users. In recent decades, there have also been transfers from agricultural uses to urban uses. Ongoing commercial and demographic expansion in the El Paso metropolitan economy increases the likelihood of additional farm-to-municipal transfers in future years. Although legal mechanisms have periodically been introduced to allow these exchanges to occur, pricing has not played a central role in the process. At present, transfers of surface water rights in El Paso County occur under fairly rigid conditions.
\end{abstract}

Keywords: Regional economic growth; Surface water rights transfers

\section{Introduction}

El Paso County is located a semi-arid region of far west Texas. Because it typically receives slightly less than $230 \mathrm{~mm}$ of rain per year, agriculture in El Paso has always depended upon a combination of surface and ground waters to be viable. Over time, a system of water rights was established for agricultural users. That system allows surface water rights to be transferred among different farm producers, although a functional market in which multiple transfers occur at negotiated prices for this category of user rights does not currently exist.

In recent decades, the category of water transfers receiving the most attention has been that involving agriculture-to-municipal transfers of existing surface water rights. These transfers are sometimes accompanied by controversy. They currently involve water-use exchanges within the county, but may eventually evolve to include regional transfers of groundwater from other parts of Texas (Phillips \& Hernández, 1998). Regional transfers from across state lines with southern New Mexico could potentially occur at some point in the future (Earl \& Czerniak, 1996). Transfers across the international

doi: 10.2166/wp.2006.031

C IWA Publishing 2006 
boundary with northern Mexico may also eventually occur. Regional water transfers across state and international borders would involve complicated negotiations, but could also allow the capture of potential economies of scale that may enable them to be successfully completed one day. Given the nature of jurisdictional concerns involving water, such a scenario is not likely in the short-term.

The material below summarizes the current state of water transfers among users and uses of the United States Bureau of Reclamation Rio Grande Project surface water in El Paso County, Texas. Specific topics covered include historical background, recent economic trends and future steps. As shown by the protracted snow drought of the early $2000 \mathrm{~s}$ at the headwaters of the Rio Grande, numerous factors can affect the availability of river water in El Paso. Greater flexibility in the management of existing rights to the water that does flow through the region each year may help stakeholders maximize their respective welfare. In addition to the different topics related to surface water rights transfers, a brief review of ground water rights transfers in Texas and how they might eventually be utilized in El Paso County is also included.

\section{Historical background}

Historically, nearly all of the Rio Grande surface water released by the United States Bureau of Reclamation every year from Caballo Dam and Elephant Butte Dam in Southern New Mexico was utilized for agricultural purposes. Under the 1906 Convention for the Equitable Division of the Waters of the Rio Grande for Irrigation Purposes, 74 million $\mathrm{m}^{3}$ per year are diverted to Mexico during normal years. Drought provisions allow for less than that amount to be diverted to Mexico during years in which the Bureau of Reclamation is forced to release smaller volumes from the New Mexico dams (Eaton \& Hurlbut, 1992). Such instances have occurred on multiple occasions during the mid-1950s, the mid1960 s, the early and late 1970 s and, most recently, in 2003. The map in Fig. 1 displays the geographic location of both reservoirs.

On the north side of the border, surface water diversions are measured in acre-feet. One acre-foot contains 43,560 cubic feet. The latter figure corresponds to approximately $1,233.5 \mathrm{~m}^{3}$. Alternatively, an acre-foot also contains 325,851 gallons. That volume is sufficient to provide a family of four persons with enough water to last approximately two years (TRNCC, 2002). El Paso County Water Improvement District 1 is the organization that delivers surface water from the Rio Grande to agricultural users within El Paso County. It also collects water rights taxes to manage the canal system that delivers the water. There are 69,010 acres of irrigable water rights land located within its boundaries. During normal years, El Paso County Water Improvement District 1 has generally received 376,860 acre-feet of water from the reservoirs in New Mexico. As occurred in 2003, droughts that affect the headwaters of the Rio Grande can lead the United States Bureau of Reclamation to release substantially less than that amount of water. Table 1 lists a subset of the various regional agencies that are involved in water distribution policy decisions in the region surrounding El Paso. The approximate geographic locations and boundaries of these organizations are also shown in Fig. 1.

In April 2003, 35,974 separate accounts held agricultural water rights managed by El Paso County Water Improvement District 1. Water allocated to all of those users is distributed through an extensive canal system. District 1 data for April 2003 indicate that a wide variety of crops are irrigated using river water. They include alfalfa, Pima cotton, pecan trees, pasture grass, onions, wheat, Upland cotton, yard grass, peppers and Sudan grass. As shown in Fig. 1, the District boundaries stretch along the portions of 


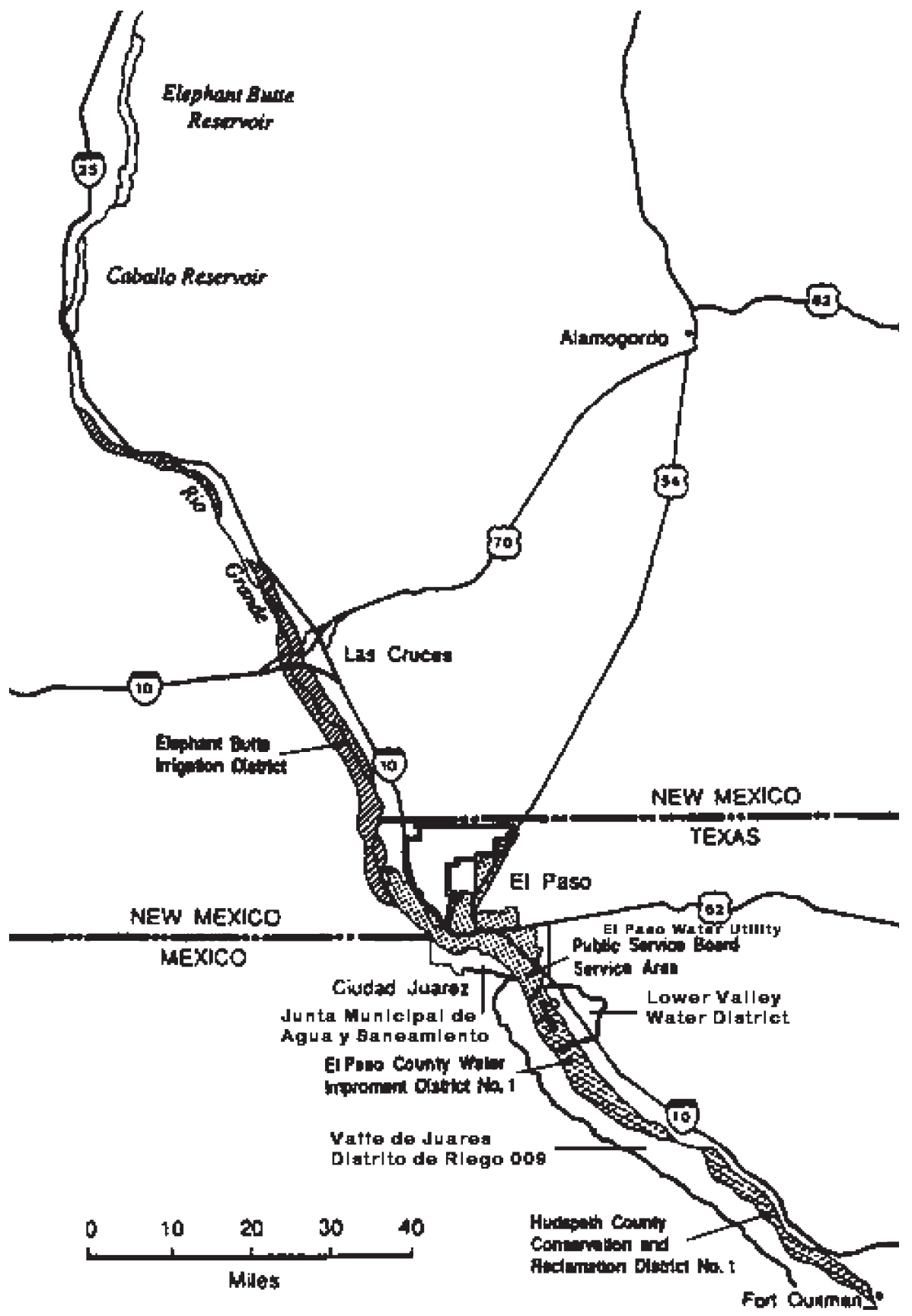

Fig. 1. El Paso regional water district boundaries.

El Paso County that lie next to the river. Owing to economic expansion and urbanization, a large portion of the district boundaries and the canal network lie within the El Paso City limits and the El Paso Public Service Board Service Area. The Public Service Board oversees El Paso Water Utilities, the municipal water authority for the city. 
Table 1. El Paso region water distribution organizations.

\begin{tabular}{ll}
\hline Organization & Charter \\
\hline United States Department of the Interior, Bureau of Reclamation & Federal agency \\
New Mexico Office of the State Engineer & State agency \\
International Boundary and Water Commission, United States & Federal Agency \\
Elephant Butte Irrigation District & Farm producers agency \\
El Paso County Water Improvement District Number 1 & State agency \\
El Paso Water Utilities & Municipal utility \\
Junta Municipal de Agua y Saneamiento de Ciudad Juárez & Municipal utility \\
Comisión Internacional de Límites y Agua, México & Federal agency \\
Comisión Nacional del Agua, México & Federal agency \\
Distrito de Riego 009, Valle de Juárez & Federal agency \\
\hline
\end{tabular}

In 1900, there were only 24,886 people residing in El Paso County and sufficient surface water was available for agricultural use. Sufficient groundwater was also available for municipal use. Demographic expansion in subsequent years was fairly rapid in El Paso and other western cities. Increasing urbanization eventually led policymakers to contract some surface water to be transferred from agricultural use to urban use (Michelsen \& Wood, 2003). Municipal uses are commonly defined as residential, commercial, industrial, public sector and other uses that are part of an urban water authority delivery system. The 1920 Act for the Sale of Project Water for Miscellaneous Purposes allowed the City of El Paso to acquire surface water as a means of reducing dependency on the Mesilla and Hueco aquifers (Cortez, 2003).

In order for the United States Secretary of the Interior to approve contracts under the 1920 Act for the sale of water for municipal and industrial uses other than irrigation, several conditions must be satisfied (Cortez, 2001). They include prior approval from El Paso County Water Improvement District 1; documentation that other practicable sources are not available; non-detriment to water service provided to other water rights holders; and crediting of moneys derived from the contracts to the United States Bureau of Reclamation fund used to manage the dams in southern New Mexico from which the water is supplied. Because water levels dropped fairly dramatically in both the Hueco and Mesilla Aquifers after 1900 , satisfying the second condition has generally been fairly straightforward to document (Tanski \& Bath, 1995).

The City of El Paso first requested conversion of existing rights under the 1920 Act in 1940. Since then, there have been a series of contracts negotiated with respect to acquiring and converting irrigation water to urban uses. On 18 February 1941, a three-party contract was negotiated between the United States Bureau of Reclamation, El Paso County Water Improvement District 1 and the City of El Paso. It allowed the City of El Paso to acquire a fee title to up to 2,000 acres of irrigable land in El Paso County and to convert the water allotted to those lands to municipal and industrial uses (Cortez, 2001). The agriculture-to-urban transfers permitted by the 1941 contract are capped at 3.5 feet of water per acre, or a maximum of 7,000 acre-feet per year. Under the 1941 contract, the City of El Paso was required to pay to the district the same annual fees and assessments as charged to agricultural users: US $\$ 15$ per acre-foot.

On 1 December 1944, a three-party contract between United States Bureau of Reclamation, the Elephant Butte Irrigation District and the City of El Paso similarly allowed municipal purchases of up to 2,000 acres of Rio Grande Project irrigated land and conversion of the appurtenant water supplies to urban uses. The 1944 contract initially seemed to be a harbinger of relatively seamless future transfers in 
response to eventual urban growth in El Paso. To date, however, the City of El Paso has not been able to take delivery of any surface water pursuant to this contract owing to legal issues that have arisen in New Mexico. Legislative barriers were adopted in Santa Fe in 1953 that made "exports" of water from New Mexico to other states such as Texas illegal (Clark, 1987). A series of legal actions during the 1980s eventually resulted in a joint agreement that calls for other steps such as building a lined canal from Caballo Dam to reduce transmission losses before additional water can be brought across the state boundary (Earl \& Czerniak, 1996).

Water rights leasing was authorized under the 20 December 1962 three-party contract negotiated between the United States Bureau of Reclamation, El Paso County Water Improvement District 1 and the City of El Paso. The 1962 contract allows owners of tracts of irrigated land to lease their water rights to the City of El Paso (Cortez, 2001). The tracts from which the water rights are leased must lie within the city limits and also within the improvement district boundaries. Land tracts that fall outside those boundaries and/or that exceed a 2-acre size limit, can still lease their water rights to the city if approved by the improvement district board of directors. Review of those applications is done on a case-by-case basis.

Water rights leases signed under the 1962 contract must be for a minimum of 25 years. Compensation to be paid by the city to the landowners was not specified in the contract. The city was required to pay the district's annual taxes and assessments for the leased water rights on behalf of the landowners. Leases signed under the 1962 contract can be renewed for additional 25-year periods unless El Paso Water Utilities is notified in writing that the landowners elect not to do so. The current lease term is 75 years. Improvement district and water utility data banks indicate that approximately 5,390 acres of water rights are currently leased from 14,706 separate accounts under the 1962 contract.

Rapid growth of unincorporated, low-income "colonia" neighborhoods led to the establishment of the 400-square-mile Lower Valley Water District in 1983. The 29 November 1988 three-party contract between United States Bureau of Reclamation, El Paso County Water Improvement District 1 and the Lower Valley Water District allows owners of tracts of irrigated land to lease their rights to water to the Lower Valley Water District. The financial aspects of the 1988 contract were the same as those of the 1962 contract with the city. As with the earlier contract, the lease prices do not anticipate changes in response to variant economic conditions. Similar to the situation within the El Paso Water Utility service area, the southeastern portion of El Paso County Water Improvement District 1 overlaps with the Lower Valley Water District.

A major institutional change was introduced by a series of three water conversion contracts executed in 1998 and 1999. In compliance with the National Environmental Policy Act, the price per acre-foot for water transferred from agricultural uses to municipal and industrial uses must be market driven (Cortez, 2001). Such a policy represents an important advance that is internationally not very common, in spite of the solid logic that underlies it (Anonymous, 2003). Eventually, that step should help ensure that the surface water that El Paso County Water Improvement District 1 receives from the New Mexico reservoirs is used efficiently (Michelsen, 1994).

More recently, an agreement was reached between the City of El Paso and El Paso County Water Improvement District 1 regarding a forbearance framework to allow farmers to sell up to $85 \%$ of the irrigation water available to them to the city (Meritz, 2004). Water rights forbearance allows a municipal water utility to negotiate with landowners for permission to use surface water rights for a specified period of time. Although still subject to approval by the United States Bureau of Reclamation, the new agreement brings El Paso County one step closer to a system under which 
a broader and more frequent, set of exchanges can occur than what has previously occurred. Further improving overall flexibility, the 2004 agreement also allows surface rights transfers from tracts of land that cover more than 2 acres.

District 1 irrigation water that is converted from agriculture to miscellaneous purposes can come from several sources (Cortez, 2001). One is from land that will no longer be irrigated owing to changes in use, such as withdrawal from production for commercial development. A second source may be from land where the owner will not use all of the water available for irrigation and is willing to supply a portion of it to a third party. Production shifts to crops that require less water occasionally lead to this circumstance. A third source may be from improvements in efficiency, recovery or conservation in the district's water delivery system. A primary example of the latter is the additional water that becomes available after canals are lined to reduce seepage losses. Recent estimates indicate that annual savings from ten miles of canal lining could provide enough water for 8,000 households (Sheng \& King, 2003).

Several important administrative steps must also be taken to convert the Rio Grande Project irrigation water to urban uses under the 1920 Act (Cortez, 2001). A meeting must first be conducted between representatives from the United States Bureau of Reclamation El Paso Field Office, El Paso County Water Improvement District 1 and the third party contractor wishing to transfer the water supply to one of the various miscellaneous uses other than agriculture. The third party contractor will generally be a utility, such as El Paso Water Utility or the Lower Valley Water District, but may also be a separate body, such as an environmental protection organization. Next, a master conversion contract must be drawn up between the Reclamation El Paso Field Office, Improvement District 1 and the third party contractor.

Subsequent to that step, a three-party Third Party Implementing Contract is executed between the Reclamation El Paso Field Office, Improvement District 1 and the third party contractor. The implementing contract, among other things, authorizes the conversion in use and identifies the specific source, or sources, of the surface water. Finally, any contract involving a conversion of water to municipal and industrial uses that is executed by a landowner, water resource entity and Improvement District 1, must be reviewed and approved by the United States Bureau of Reclamation (Cortez, 2001). In addition to these procedural steps, pricing, subject to existing agreements governing earlier exchanges, will be market-driven. A federal fee of US\$5 per acre-foot or 5\% of the purchase price must also be paid to the United States Bureau of Reclamation. Federal administrative costs must also be covered by the water resource entity. The 2004 agreement between the city and the district should help ensure that this process is executed in a fairly smooth manner (Meritz, 2004).

\section{Recent and current economic trends}

Numerous steps remain to be taken with respect to establishing a final framework that allows more flexible agriculture-to-metropolitan water transfers in El Paso County. There are, however, a variety of factors that make eventual attainment of such a system likely. Two basic price sets determine the attractiveness of leasing water from agriculture to other uses, crop prices and water prices (Gardner \& Miller, 1983; Gardner \& Young, 1984). In recent years, the value of El Paso County agricultural output has declined (Herendeen, 2003). Total farm acreage has also dropped substantially below the peak level observed in 1954 (Table 2). The latter items, in part, reflect farm prices that have generally increased at 
relatively slow rates and have also been subject to periodic declines in real terms. Given the municipal and industrial trends reviewed below, there is reason to believe that the prices at which water would have been converted to other uses in recent years could have trended upwards if a more flexible system for transfers had existed. One estimate places the 2004 value of an acre-foot at US\$200 (Meritz, 2004).

The biggest reason for passage of the 1920 Act for the Sale of Project Water for Miscellaneous Purposes was anticipated western state population growth. Demographic expansion has continued subsequent to 1941 when the first irrigation water transfers occurred. Increases in the local population bases have caused the levels of the Hueco and Mesilla aquifers to decline substantially (Tanski \& Bath, 1995). Additional population growth is also forecast on a long-run basis for El Paso, Ciudad Juárez and Las Cruces (Peach, 2000; Fullerton \& Tinajero, 2004). Table 3 summarizes historical and projected population levels for the three urban economies that jointly comprise the borderplex metropolitan area that straddles three domestic state boundaries and one international border.

It is easy to see that demographic trends probably would translate into upward price movements for surface water transfers in a more market-oriented context. Those pressures would have been reinforced by real income growth in the borderplex during this period. Table 4 contains historical and projected real total and per capita incomes for the El Paso metropolitan economy. Simply put, increases in effective purchasing power almost always lead to higher prices for scarce commodities such as water whose supplies are not expanding rapidly, if at all. In recent years, there has been a difference of opinion between the Improvement District and El Paso Water Utilities over what the price for water rights transfers should be (EPWU, 2002). Research for other western cities indicates, however, that water prices in general throughout the region may be lower than advisable and should increase (Brookshire et al., 2002; MacLeod \& Smith, 2003). As more transfers occur, evidence will become available regarding local market valuation of irrigation water.

Additional pieces of evidence also indicate that a market-based system for water rights transfers would have led to higher prices. On the different occasions when rates have been established (1941, 1962, 2001) for different categories of agriculture-to-urban transfers in El Paso County, the average price per acre-foot has increased. An upward trend can also be observed using El Paso Water Utilities

Table 2. El Paso County farm and acreage trends.

\begin{tabular}{llr}
\hline Year & Farms & Acreage \\
\hline 1954 & 690 & 589,309 \\
1959 & 482 & 518,335 \\
1964 & 403 & 513,752 \\
1969 & 452 & 445,872 \\
1974 & 317 & 386,596 \\
1978 & 380 & 333,005 \\
1982 & 452 & 299,665 \\
1987 & 422 & 236,667 \\
1992 & 438 & 245,000 \\
1997 & 530 & 249,165 \\
2002 & 600 & 113,948 \\
\hline
\end{tabular}

Source: United States Census of Agriculture, various issues. Not all farms in El Paso County are irrigated. The acreage for 1992 is estimated. United States Bureau of Reclamation data for 1954 through 1999 indicate that El Paso County irrigated acreage oscillated between 45,000 and 61,000 acres each year. 
Table 3. Borderplex population trends.

\begin{tabular}{lccc}
\hline Year & El Paso & Cd. Juárez & Las Cruces \\
\hline 1970 & 360.462 & 414.908 & 70.254 \\
1980 & 483.711 & 567.365 & 81.979 \\
1990 & 595.350 & 798.499 & 136.593 \\
2000 & 681.700 & 1218.817 & 175.028 \\
2010 & 764.439 & 1567.160 & 203.826 \\
2020 & 843.769 & 1992.740 & 240.171 \\
\hline
\end{tabular}

Units: 1000 s. Source: Fullerton \& Tinajero, 2004 and University of Texas at El Paso Border Region Modeling Project.

annual operations data for water and wastewater. As shown in Table 5, per gallon fees have historically, but not always, more than kept pace with inflation. El Paso Water Utilities recently reaffirmed plans to raise water rates in real terms in future years (Mrkvicka, 2003a; Wilson, 2003). The latter decision is important because whenever El Paso Water Utilities, similar to other metropolitan utilities, has raised rates in the past, per capita consumption has declined across customer classes (Fullerton \& Schauer, 2001; Griffin, 2001; Fullerton \& Elias, 2004). Among important metropolitan economies in the desert southwest, El Paso has one of the lowest per capita consumption usage levels (EPWU, 2002). Despite this, growth in the number of users in each customer class usually prevents total municipal and industrial water consumption levels from falling in El Paso (Tables 6 and 7).

The above material examines issues involving transfers of rights to use Rio Grande surface water. Groundwater rights in Texas receive very different legal treatment compared with surface water rights. While subject to Texas Commission on Environmental Quality groundwater quality restrictions, groundwater generally belongs to landowners (Fambrough, 2002). Similar to minerals, however, groundwater rights can also be sold or leased separate from the land under which the water is found. Although groundwater leasing is legal in Texas, numerous questions have yet to be considered by the judicial system including those that involve regional transfers from part of the state to another.

Because the price for such geographic transfers is negotiable, it improves the likelihood that "water imports" from counties such as Hudspeth, Culberson, Jeff Davis and Presidio may one day occur. In addition to the lease price for the water, however, it is important to recognize that the pipelines required to transport it would be expensive to build and manage. Investment in such a conveyance system would be preceded by possibly lengthy discussions with regional conservation districts and state planning

Table 4. El Paso real income trends, 1996 US\$.

\begin{tabular}{lrr}
\hline Year & Total & Per capita \\
\hline 1970 & $\$ 3,710$ million & $\$ 10,292$ \\
1980 & $\$ 5,559$ million & $\$ 11,491$ \\
1990 & $\$ 8,534$ million & $\$ 14,335$ \\
2000 & $\$ 11,737$ million & $\$ 17,212$ \\
2010 & $\$ 15,057$ million & $\$ 19,508$ \\
2020 & $\$ 17,692$ million & $\$ 21,163$ \\
\hline
\end{tabular}

Source: Fullerton \& Tinajero, 2004 and University of Texas at El Paso Border Region Modeling Project. Total real income is reported in millions of 1996 US dollars. Real per capita income is reported in 1996 US dollars. The United States personal consumption expenditures deflator is used to adjust the data. 
Table 5. El Paso water utility average per gallon water charges.

\begin{tabular}{lll}
\hline Year & Nominal US\$ & Real 1996 US\$ \\
\hline 1980 & 0.75 & 1.35 \\
1985 & 1.27 & 1.78 \\
1990 & 1.50 & 1.75 \\
1995 & 1.98 & 2.02 \\
2000 & 2.32 & 2.16
\end{tabular}

Source: Water and wastewater gallon and revenue data used in the calculations are from El Paso Water Utilities. The United States personal consumption expenditures deflator is used to adjust the data.

agencies. Beyond leasing land from existing owners, El Paso Water Utilities has also purchased ranchland at several locations in West Texas in anticipation of eventual importation of groundwater from those areas (Archuleta, 2003). Progress involving county-to-county groundwater transfers is likely to be slow and deliberate, but offers an additional source of water for El Paso and other western urban areas that may eventually be tapped (Crowder, 2003). Concerns regarding regional economic losses resulting from reductions in agricultural and other activities can potentially be addressed by imposing "transfer taxes." Monies from the latter mechanisms can be used to replace anticipated reductions in property tax revenues and other fiscal lines, thus minimizing adjustment difficulties that may be faced in groundwater exporting jurisdictions (Gardner, 1990).

\section{Future directions}

Ongoing borderplex economic expansion guarantees that the demand for water will continue to grow in El Paso. A mix of conservation efforts have also been utilized for more than a decade to lower per capita demands (Schmandt, 2002). In spite of these efforts, limited local groundwater development options caused by salinity and other problems imply that surface water from the Rio Grande will be likely to play a central role in supplying future urban water requirements (Flynn, 2003). This requires transfer of water rights from agriculture to other uses, as has occurred in other regions of the western United States (Randall, 1981; Weatherford \& Shupe, 1986). Under normal spring run-off conditions, approximately 376,860 acre-feet of surface water per year can be diverted from the river to District 1 agricultural users in El Paso County.

Table 6. El Paso water utility meters in service.

\begin{tabular}{lllcrr}
\hline Year & SF-residential & MF-residential & Commercial & Industrial & Other \\
\hline 1970 & 59.417 & 4.247 & 5.161 & 0.136 & 1.899 \\
1980 & 88.697 & 4.742 & 6.609 & 0.096 & 1.657 \\
1990 & 110.692 & 4.918 & 7.746 & 0.140 & 5.538 \\
2000 & 133.879 & 4.758 & 8.828 & 0.207 & 16.277 \\
2010 & 157.578 & 4.879 & 9.597 & 0.179 & 27.776 \\
2020 & 179.643 & 4.868 & 10.872 & 0.111 & 40.237 \\
\hline
\end{tabular}

Units: 1000 s. Source: Fullerton \& Tinajero, 2004 and University of Texas at El Paso Border Region Modeling Project. Residential accounts are classified as either single-family (SF) or multi-family (MF). 
Table 7. El Paso municipal and industrial water consumption.

\begin{tabular}{lllllr}
\hline Year & SF-residential & MF-residential & Commercial & Industrial & Other \\
\hline 1970 & 13.989 & 1.576 & 3.062 & 0.887 & 2.898 \\
1980 & 16.551 & 2.626 & 4.967 & 0.890 & 3.908 \\
1990 & 17.546 & 4.304 & 6.526 & 1.275 & 4.286 \\
2000 & 20.338 & 3.699 & 4.574 & 0.714 & 6.697 \\
2010 & 22.483 & 3.876 & 4.462 & 0.410 & 10.674 \\
2020 & 24.981 & 6.771 & 5.132 & 0.260 & 16.566 \\
\hline
\end{tabular}

Units: Billion gallons. Source: Fullerton \& Tinajero, 2004 and University of Texas at El Paso Border Region Modeling Project. Residential accounts are classified as either single-family (SF) or multi-family (MF).

There is already a long history of water transfers in El Paso County. Historically, most of the transfers that have occurred have been between agricultural users. A growing number involve transfers from agriculture to municipal and industrial uses. The water rights exchanges to date have not been documented in a manner that allows them to be researched very extensively. Development of a registry of historical transactions would allow specific characteristics associated with El Paso County to be investigated, documented and quantified. The 2004 agreement between the City of El Paso and El Paso County Water Improvement District 1 raises the possibility of relatively flexible exchanges between agricultural and municipal uses in the foreseeable future. These transactions are expected to occur at market prices that are negotiated between the different parties involved.

Pressures to transfer water from agricultural uses to metropolitan and/or other uses arise because the alternative uses place higher value on the water (Michelsen, 1994). Agricultural water rights holders in El Paso County Water Improvement District 1 may wish to examine the potential gains associated with competitively priced short-term leases relative to those associated with longer-term leases of their respective rights. This would require movement in the direction of a more flexible system than currently exists, but can be accomplished using existing contractual tools and mechanisms if they are more fully developed. Movement in this direction would potentially allow different parties to achieve economic and financial gains while reducing the number of legislative and judicial confrontations that have occasionally flared in the region (Mrkvicka, 2003b).

Establishing a more operational water market will require additional time and analysis. Highly competitive markets are characterized by large numbers of buyers and sellers. Because the geographic extent of El Paso County is limited, the City of El Paso would be likely to account for a large percentage of the transfers that could eventually occur. Given this prospect, it may be in the interest of agricultural water rights to sign short-term leasing agreements until better information is available regarding price trends. Wide variations in prices have been observed in markets where few transactions occur and the number of participants is limited (Colby et al., 1993; Michelsen, 1994). In spite of the uncertainty over price, the waters of the Rio Grande are largely appropriated and the introduction of market mechanisms for water transfers makes sense (Gardner, 1985). Metropolitan growth and municipal water pricing practices in El Paso have helped local parties understand that water prices in general are rising.

Establishment of an active water market would also require a reduction in institutional restrictions and transaction costs. The 2004 agreement regarding forbearance contracts will potentially go a long way towards achieving this goal. Although the time frame and administrative fees to be charged for each transfer to be transacted are still unclear, as experience is gained, the transfer process will probably 
become more functional. Among the administrative steps to be taken would be downstream impact reviews, title searches and application filings. To the extent that it is possible, establishing flat fees and relatively short time limits for approval decisions would be helpful. The El Paso Public Service Board, the five-member board of trustees that has oversight with respect to El Paso Water Utilities, has also recommended removing the requirement that the United States Bureau of Reclamation approve any contractual transfers that are negotiated (Mrkvicka, 2003b). Improvement District 1 officials have historically opposed this, but other means for streamlining the process probably exist. Bureau of Reclamation approval of the 2004 agreement is still pending, but is expected.

An additional market-oriented innovation that might prove helpful during drought years like 2003 is a system of option contracts for temporary use of irrigation water (Michelsen \& Young, 1993). For years when snowfalls are too light to support normal stream flows and releases from the reservoirs, El Paso Water Utilities would be able to exercise option contracts to transfer water from agriculture to municipal uses. The striking price of each option would cover the losses in output values faced by agricultural operators as a consequence of relinquishing their water allotments when river flows are expected to fall by a certain percentage below average. Dry year options for temporary leases would have proved helpful in 2003 when Stage 2 Water Restrictions were enacted by the City of El Paso (Characklis et al. 1999). To pay for the cost of exercising the options and encourage additional conservation, temporary surcharges could also be added to water utility bills for the metropolitan customers (Fullerton \& Elias, 2004).

Water rights associated with the annual allotments to El Paso County Water Improvement District 1 by the United States Bureau of Reclamation are managed largely in isolation from southern New Mexico and northern Mexico. Establishment of a better functioning system of transfers can probably be enhanced by coordinating usage across a wider geographic region than just El Paso County (Earl \& Czerniak, 1996). Allowing El Paso Water Utilities to "import" water from New Mexico and also provide service to growing cities such as Anthony and Sunland Park would allow those municipalities to take advantage of the economies of scale available from cooperating on larger production and distribution volumes. Similarly, it may make sense to set up mechanisms that allow El Paso Water Utilities to assist the Ciudad Juárez Junta Municipal de Agua y Saneamiento with treatment facility plant investments and other means of preserving and/or extending existing supplies (Gutiérrez, 2001). Efficient water transfers and usage markets elsewhere in the western United States have generally involved multiple jurisdictions and locations (Howe et al., 1986; Michelsen, 1994).

\section{Conclusion}

Similar to other regions in the western United States, surface water rights transfers among agricultural users have occurred in El Paso County for many decades. Readily accessible documentation regarding those transactions does not currently exist. Federal legislation passed in 1920 provides a general framework under which United States Bureau of Reclamation Rio Grande Project irrigation water may also be transferred to miscellaneous uses such as municipal, industrial and environmental uses. The first contract to allow agriculture-to-urban transfers was approved in 1941.

Continued economic and demographic growth over the course of the last six decades has led to the development of contracts that permit leasing of rights to use water to the City of El Paso, as well as to the Lower Valley Water District. Additional contracts have also been designed to allow for the leasing of rights to use water to occur. Reduced groundwater levels in the Mesilla and Hueco aquifers has increased 
the implied value of the irrigation waters released every year from the Caballo Lake and Elephant Butte reservoirs. The reduced availability of clean groundwater has also meant that questions about the transference of irrigation waters from agriculture to municipal and industrial uses have received more attention in recent years.

The basic institutional mechanisms are in place for a greater number of rights to water transfers to occur in El Paso County. Agreement between the city and the irrigation district on the forbearance contract represents an important milestone, but there will probably be additional steps required to reduce other institutional constraints on water rights transactions. Given the limited number of transactions that have occurred to date, it is not clear what initial pricing patterns will emerge. Recent events indicate that realistic price ranges are being considered. Allowing more active trading and negotiations over water rights to occur in El Paso County should help maximize usage efficiency as well as owner benefits. Eventually, it may be helpful also to permit water exchanges across state and international boundaries as a means of capturing economies of scale in distribution networks and treatment facilities.

Several tentative policy implications may be drawn from the El Paso County experience. For regions where intra-sectoral water rights transfers take place, a public registry can help improve insight to the factors that motivate those exchanges and the conditions under which they occur. In regions where intersectoral transfers are anticipated, flexible pricing should help facilitate the process. For farm producers, it will allow them to be compensated for temporarily relinquishing the rights to a critical input. For municipal utilities, it will help ensure access to water during shortages. In regions where state, provincial and/or international borders are present; cross-boundary leasing flexibility should be considered. Regional watersheds frequently defy geopolitical boundaries and efficient utilization of these resources will be likely to require jurisdictional cooperation between multiple public agencies.

\section{Acknowledgements}

Funding support for this research was provided by the William and Flora Hewlett Foundation, the El Paso Electric Company, the El Paso Metropolitan Planning Organization, the City of El Paso Office of Economic Development, Wells Fargo Bank of El Paso, a National Science Foundation Grant SES0332001 and a Southwest Center for Environmental Research and Policy SCERP Grant W-04-03. Helpful comments were provided by José Z. García, Chris Brown, Bert Cortez, Ed Fierro, Edd Fifer, David Torres, Mike Fahy, Wayne Treers, Bob Czerniak, Martha Patricia Barraza, Roberto Tinajero and two anonymous referees. Research assistance was provided by Marycruz De Leon and Brian Kelley.

\section{References}

Anonymous (2003). Priceless. The Economist, (19 July), 3-16.

Archuleta, E. (2003), How a large municipality plans to meet its future water supply needs. Proceedings of the 45th Annual New Mexico Water Conference. Las Cruces, NM. New Mexico State University Water Resources Research Institute Report 326, pp. 81-93.

Brookshire, D. S., Burness, H. S., Chermak, J. M. \& Krause, K. (2002). Western urban water demand. Natural Resources Journal, 42, 873-898.

Characklis, G. W., Griffin, R. C. \& Bedient, P. B. (1999). Improving the ability of a water market to efficiently manage drought. Water Resources Research, 35, 823-831. 
Clark, I. G. (1987). Water in New Mexico: A History of its Management and Use. University of New Mexico Press, Albuquerque, NM.

Colby, B. G., Crandall, K. \& Bush, D. B. (1993). Water rights transactions: market values and price dispersion. Water Resources Research, 29, 1565-1572.

Cortez, F. (2001). Competition for water among agricultural, municipal, environmental and other uses. Paper presented at Southwestern Pecan Growers Conference, Las Cruces, NM.

Cortez, F. (2003). Welcome! Rio Grande Project El Paso and Elephant Butte Field Divisions, United States Bureau of Reclamation, www.usbr.gov/uc/elpaso/aboutus/fdmwel.html web site.

Crowder, D. (2003). Hudspeth water lease proposal worries some. El Paso Times, (December 2), $1 \mathrm{~B}$.

Earl, R. A. \& Czerniak, R. J. (1996). Sunbelt water war: The El Paso - New Mexico water conflict. Social Science Journal, 33, 359-379.

Eaton, D. J. \& Hurlbut, D. (1992). Challenges in the Binational Management of Water Resources in the Rio Grande / Río Bravo. University of Texas Lyndon B. Johnson School of Public Affairs US-Mexican Policy Report 2, Austin, TX.

EPWU (2002). Water: Nothing Can Replace It. El Paso Water Utilities mimeograph, El Paso, TX.

Fambrough, J. (2002). Secrets for Negotiating Texas Groundwater Leases. Texas A\&M Real Estate Center Technical Report 1593, College Station, TX.

Flynn, K. (2003). Profits evaporate. El Paso Times, (August 17), 1E-2E.

Fullerton, T. M., Jr. \& Elias, A. (2004). Short-term water consumption dynamics in El Paso, Texas. Water Resources Research, 40, W082011-W082017.

Fullerton, T. M., Jr. \& Schauer, D. A. (2001). Regional econometric assessment of aggregate water consumption trends. Australasian Journal of Regional Studies, 7, 167-187.

Fullerton, T. M., Jr \& Tinajero, R. (2004). Borderplex Long-Term Economic Trends to 2023. University of Texas at El Paso Border Region Modeling Project Business Report SR04-1, El Paso, TX.

Gardner, R. L. (1985). The potential for water markets in Idaho. Idaho Economic Forecast, 7, (Summer), $27-34$.

Gardner, R. L. (1990). The impacts and efficiency of agriculture-to-urban water transfers: discussion. American Journal of Agricultural Economics, 72, 1207-1209.

Gardner, R. L. \& Miller, T. A. (1983). Price behavior in the water market of northeastern Colorado. Water Resources Bulletin, 19, 557-562.

Gardner, R. L. \& Young, R. A. (1984). The effects of electricity rates and rate structure on pump irrigation. Land Economics, $60,352-359$.

Griffin, R. C. (2001). Effective water pricing. Journal of the American Water Resources Association, 37, $1335-1347$.

Gutiérrez, L. M. (2001). International border water issues. In Proceedings of the 45th Annual New Mexico Water Conference. NMSU WRRI Report 319, Las Cruces, NM, pp. 17-22.

Herendeen, J. B. (2003). The role of agriculture in the El Paso area. In Dígame: Policy and Politics on the Border, Chapter 18. Thurlow Brenner, C., Coronado, I. \& Soden, D. L. (eds). Kendall Hunt, Dubuque, IA.

Howe, C. W., Schurmeier, D. R. \& Shaw, W. D., Jr. (1986). Innovative approaches to water allocation: the potential for water markets. Water Resources Research, 22, 439-445.

MacLeod, M. \& Smith, E. (2003). Economic Principles for Sound Water Planning: An Introduction for Regional Water Planning Groups in Texas. Environmental Defense, Austin, TX.

Michelsen, A. M. (1994). Administrative, institutional and structural characteristics of an active water market. Water Resources Bulletin, 30, 971-982.

Michelsen, A. M. \& Wood, M. K. (2003), Water demand in the Paso del Norte region. Paper presented at University of Texas at El Paso TransBoundary Water Conference (March).

Michelsen, A. M. \& Young, R. A. (1993). Optioning agricultural water rights for urban supplies during drought. American Journal of Agricultural Economics, 75, 1010-1020.

Meritz, D. (2004). City can buy farmers' water. El Paso Times, (May 24), 1 B.

Mrkvicka, M. (2003a). Water: Is rationing the best solution? El Paso Inc., (March 16-22), 1a, 5a.

Mrkvicka, M. (2003b). Why El Paso is trying to grab farmers' water. El Paso Inc., (February 23-March 1), 1a, 5a-6a.

Peach, J. (2000). Demographic trends and water demand: New Mexico, El Paso and Ciudad Juárez. In Proceedings of the 44th Annual New Mexico Water Conference. Las Cruces, NM, pp. 180-185. 
Phillips, K. \& Hernández, B. (1998). Market solutions to water allocation in Texas. Federal Reserve Bank of Dallas VISTA South Texas Economic Trends and Issues, (May), 1-5.

Randall, A. (1981). Property entitlements and pricing policies for a maturing water economy. Australian Journal of Agricultural Economics, 25, 195-212.

Schmandt, J. (2002). Bi-national water issues in the Rio Grande/Río Bravo basin. Water Policy, 4, 137-155.

Sheng, Z. \& King, P. J. (2003). TAMU and NMSU Scientists Help Irrigation Districts in Water Conservation. Texas A\&M Agricultural Research and Extension Center at El Paso, El Paso, TX (July).

Tanski, J. M. \& Bath, C. R. (1995). Resolving water disputes along the US-Mexico Border. New Mexico State University Border Research Institute, Las Cruces, NM.

TRNCC (2002). Rights to Surface Water in Texas. GI-228, Texas Commission on Environmental Quality, Austin, TX.

Weatherford, G. D. \& Shupe, S. J. (1986). Reallocating water in the west. Journal of the American Water Works Association, 78, 63-71 (October).

Wilson, C. K. (2003). Search for solutions. El Paso Times, (March 18), 5B. 